\title{
A Study of Post COVID Foot Arthralgia
}

\author{
Satya Kumar koduru ${ }^{1 *}$, Shravya ${ }^{1}$, Sateesh $^{2}$, V V Narasimha Rao ${ }^{2}$ and V Satya Kiran Raju ${ }^{2}$ \\ ${ }^{1}$ Senior Resident, Department of Orthopaedics, NRI Academy of Sciences, India \\ ${ }^{2} J$ unior resident, Department of Orthopaedics, NRI Academy of Sciences, India
}

Submission: February 06, 2021; Published: February 22, 2021

*Corresponding author: Dr. K Satya Kumar, Prof \& Hod, Department of Orthopaedics, NRI Academy Of Sciences, Chinakakani, Guntur(Dt), Andhra Pradesh, India

Abstract

Aim: To evaluate the reasons of post covid foot arthralgia \& its relation to flat foot.

Objectives: To Evaluate and analyses the reasons for poly arthralgia in the foot in post covid Infected patients

Introduction: About 15\% of patients with COVID-19 present with arthralgia at some point, but not much is known about the nature or presentation of such rheumatic manifestations of this infection. However, it is well-known that viral infections are associated with acute joint inflammation and pain, including single joint involvement with viruses such as the chikungunya virus, hepatitis B virus, hepatitis $\mathrm{C}$ virus, parvovirus, Epstein-Barr virus, and HIV.

Materials \& Methods: The analysis was carried out in NRI General Hospital \& Orthocare, vijayawada from May 2020 to December 2020. The Total Number of Cases reported \& analysed were 12 with the age ranges between $30-80$ years. 8 were female and 4 were male patients.

Results: 12 patients came to OPD with post covid foot arthralgia. Out of 12 patients, 8 (66.66\%) patients were diagnosed with medial longitudinal arch loss and 4 (33.33\%) patients with normal arch. All the patients were treated with analgesics for 2 weeks, oral low dose steroid for 1 month and medial longitudinal arch support. Patients showed subsidence in pain and normal values of inflammatory markers. Post covid foot arthralgia was not associated with the antibodies detected.

Conclusion: We conclude from our study that analgesics, oral low dose steroid, medial longitudinal arch support can be considered as rational method of treating post covid foot arthralgia.

\section{Introduction}

COVID-19 is an acute infectious disease caused by severe acute respiratory syndrome corona virus-2 (SARS-CoV-2),primarily affecting lungs leading to excessive and uncontrolled immune activation, cytokine response on alveolar structure, triggering severe inflammatory pathways. The recent outbreak in India is the result of global pandemic which were first reported as cluster of pneumonia from Wuhan, China in 2019. The report of post infection complication including foot arthralgia with intermittent or continuous foot pain experienced during recovery [1]. The treatment plans consisting of supportive(medial longitudinal arch support) and short course of symptomatic care were found to be beneficial for alleviation of symptoms, though specific treatment modalities did not exist. About $15 \%$ of patients with

COVID-19 present with arthralgia at some point, but not much is known about the nature or presentation of such rheumatic manifestations of this infection. However, it is well-known that viral infections are associated with acute joint inflammation and pain, including single joint involvement with viruses such as the Chikungunya virus, Hepatitis B virus, Hepatitis C virus, Parvo- virus B-19, Epstein-Barr virus, and HIV. A follow up study of Covid-19 consequences of foot arthralgia was evaluated in 12 patients [2]. They presented with foot pain, swelling of foot, elevated inflammatory markers( Erythrocyte sedimentation rate and C-reactive protein) and no consideration of anti SARS CoV-2

IgG antibodies. Antibodies were evaluated for understanding of disease, effects on treatment with foot arthralgia (Figure 1).

Aim

To evaluate the reasons of post covid foot arthralgia \& its relation to flat foot. 


\section{Orthopedics and Rheumatology Open Access Journal (OROAJ)}

\section{Objective}

To evaluate and analyze the reasons for poly arthralgia in the foot in post covid infected patients.

\section{Materials \& Methods}

NRI General Hospital, Chinakakani was designated as the dedicated Covid-19 treatment hospital by the Government of Andhra Pradesh. With the tertiary care facilities available, we treated about 12,500 Covid-19 patients during this pandemic [3]. A post covid care Outpatient Department was specifically started by our hospital as many patients were suffering from multiple complications following recovery from Covid-19 infection. The analysis was Carried Out in NRI General Hospital \& Orthocare, Vijayawada From May 2020 to December 2020. The total number of cases reported $\&$ analyzed were 12 with the age ranges between 30-80 years. 8 were female and 4 were male patients (Figures $2 \&$ $3)$.

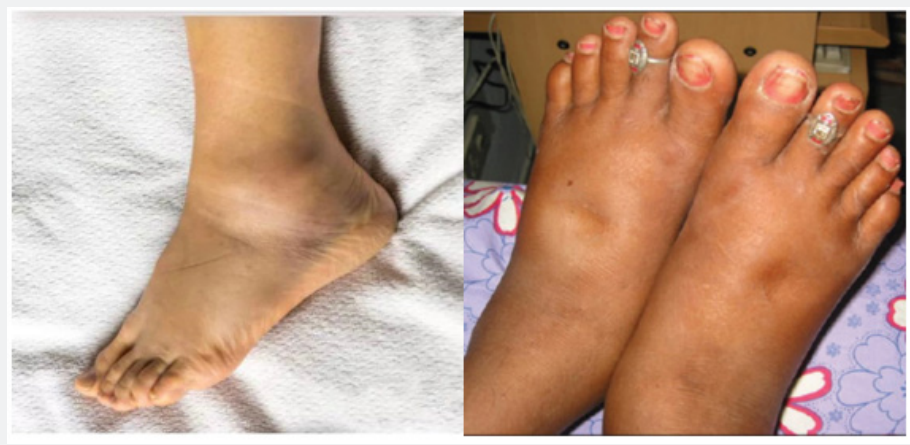

Figure 1: Foot arthralgia.

AGE

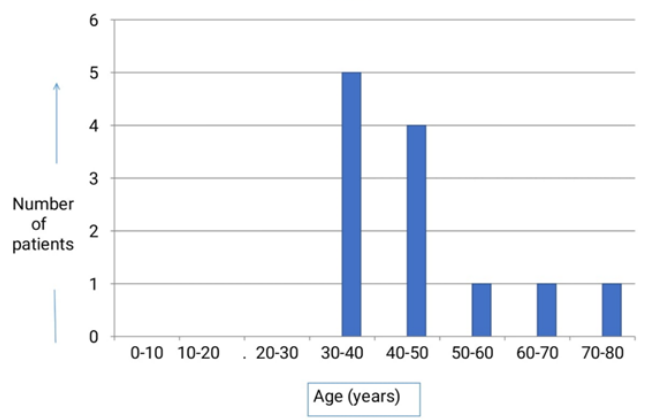

Figure 2:

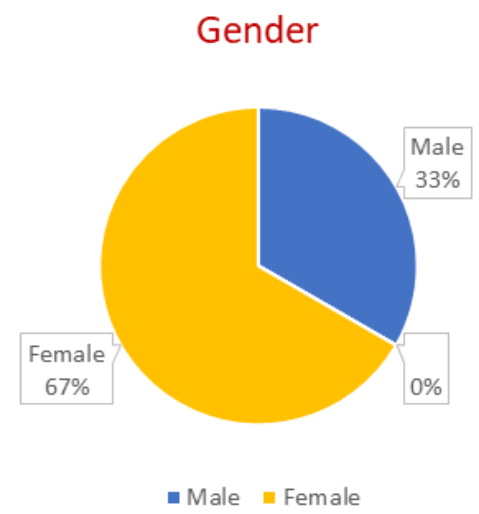

Figure 3 


\section{Inclusion Criteria}

Males and females of age group 30-80 years. Patients who give consent for antibodies detection.

\section{Exclusion Criteria}

Patients who have all other Musculo skeletal manifestations like gouty arthritis and rheumatoid arthritis. Patients who have confounding comorbid conditions.

\section{Treatment}

All the 12 patients were treated with analgesics( CELECOXIB 200mg BD for 2 weeks) and tapering dose of low dose oral steroid (METHYL PREDNISOLONE for 1 month). Out of 12, 8 patients did not have significant pain relief and they were treated with medial longitudinal arch support. Follow up was done at 1,3 and 6 months.

\section{Results}

12 patients came to OPD with post covid foot arthralgia. Out of 12 patients, $8(66.66 \%)$ patients were diagnosed with medial longitudinal arch loss and 4 (33.33\%) patients with normal arch. All the patients were treated with analgesics for 2 weeks, oral low dose steroid for 1 month and medial longitudinal arch support. Patients showed subsidence in pain and normal values of inflammatory markers. Post covid foot arthralgia was not associated with the antibodies detected.

\section{Discussion}

12 patients visited to Outpatient Department with post covid foot arthralgia. Since Covid-19 is a new and emerging pandemic where there is no scientific evidence regarding the pathogenesis, transmission and management of this Covid-19 infection. In view of ongoing pandemic circumstances of Covid-19,physical examination was not feasible, thus based on the history, analgesics( CELECOXIB 200mg BD for 2 weeks) and tapering dose of low dose oral steroid (METHYL PREDNISOLONE for 1 month) were advised to all 12 patients.

Out of 12, 8 patients did not have significant pain relief and hence local examination was done. The patients were found to have developed loss of medial longitudinal arch, and these 8 patients were treated with medial longitudinal arch support. All of them had good pain relief. Out of 12 patients, 7 patients developed covid antibodies whereas 5 patients did not show covid antibodies in the serum [4-6]. There is no relation between the development of antibodies and post covid foot arthralgia. Patients had no consideration of antibodies, pain and inflammatory markers regressed to normal after 6 months of follow up (Figures 4-7).

\section{Figure 4}

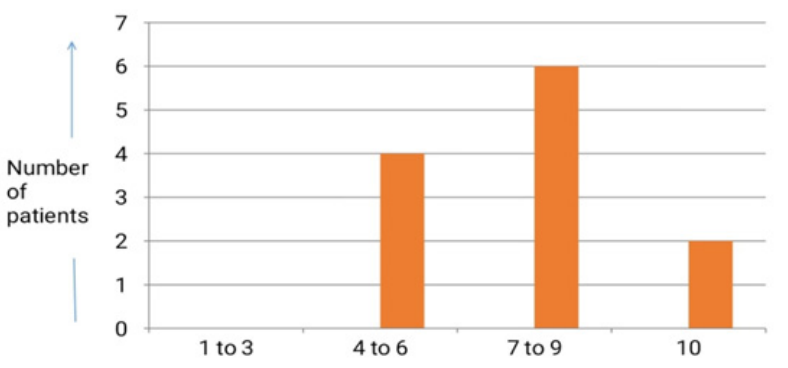

Visual analogue score

\section{Figure 5}




\begin{tabular}{|c|c|c|}
\hline \multicolumn{3}{|c|}{ Pain (based on VAS score) } \\
\hline $1^{\text {st }}$ Month & $3^{\text {rd }}$ Month & $6^{\text {th }}$ Month \\
\hline $\begin{array}{l}4 \text { patients with } \\
\text { Moderate pain } \\
2\end{array}$ & $\begin{array}{c}2 \text { patients with } \\
\text { moderate pain }\end{array}$ & $\begin{array}{l}1 \text { patient with } \\
\text { moderate pain } \\
0\end{array}$ \\
\hline $\begin{array}{l}6 \text { patients with } \\
\text { Severe pain } \\
\vdots \\
3\end{array}$ & $\begin{array}{l}3 \text { patients with } \\
\text { severe pain } \\
1\end{array}$ & $\begin{array}{c}1 \text { patient with } \\
\text { severe pain } \\
\end{array}$ \\
\hline $\begin{array}{l}2 \text { patients with Very } \\
\text { Severe pain } \\
1\end{array}$ & & $\begin{array}{l}1 \text { patient with vere } \\
\text { severe pain } \\
0\end{array}$ \\
\hline
\end{tabular}

Figure 6

Inflammatory Markers

\begin{tabular}{|l|l|l|}
\hline $1^{\text {st }}$ Month & $3^{\text {rd }}$ Month & $6^{\text {th }}$ Month \\
\hline Out of 12 patients & $\begin{array}{l}\text { Out of 4 } \\
\text { patients }\end{array}$ & End of 6 months \\
\hline $\begin{array}{l}\text { Elevated ESR \& } \\
\text { CRP in 4 Patients }\end{array}$ & $\begin{array}{l}\text { Elevated ESR } \\
\text { \& CRP in 1 } \\
\text { Patient }\end{array}$ & $\begin{array}{l}\text { No patient had } \\
\text { elevated ESR \& } \\
\text { CRP }\end{array}$ \\
\hline & & \\
\hline
\end{tabular}

Figure 7

\section{Conclusion}

We conclude from our study that analgesics, oral low dose steroid, medial longitudinal arch support can be considered as rational method of treating post covid foot arthralgia.

\section{References}

1. López-González MC, Peral-Garrido ML, Calabuig I, Ernesto TovarSugrañes, Vega Jovani, et al. (2020) Case series of acute arthritis during COVID-19 admission [Online ahead of print]. Ann Rheum Dis 2020-217914.

2. Saricaoglu EM, Hasanoglu I, Guner R (2020) The first reactive arthritis case associated with COVID-19 J Med Virol.
3. Alivernini S, Cingolani A, Gessi M, Annamaria Paglionico, Giuliana Pasciuto, et al. Comparative analysis of synovial inflammation after SARS-CoV-2 infection. Ann Rheum Dis 2020-218315.

4. Yokogawa N, Minematsu N, Katano H, Suzuki T (2020) Case of acute arthritis following SARS-CoV-2 infection. Ann Rheum Dis 2020218281.

5. Zleik N, Elfishawi MM, Kvrgic Z, Clement J Michet Jr, Cynthia S Crowson, et al. (2018) Hospitalization increases the risk of acute arthritic flares in gout: a population-based study over 2 decades. J Rheumatol 45(8): 1188- 1191

6. Logan JA, Morrison E, McGill PE (1997) Serum uric acid in acute gout. Ann Rheum Dis 56(11): 696-697. 


\section{Your next submission with Juniper Publishers} will reach you the below assets

- Quality Editorial service

- Swift Peer Review

- Reprints availability

- E-prints Service

- Manuscript Podcast for convenient understanding

- Global attainment for your research

- Manuscript accessibility in different formats ( Pdf, E-pub, Full Text, Audio)

- Unceasing customer service

Track the below URL for one-step submission https://juniperpublishers.com/online-submission.php 